JANUSZ PIECHOWICZ*, PAWEŁ PAWLIK*

\title{
MULTICHANNEL DATA ACQUISITION SYSTEM FOR VIBROACOUSTIC SIGNALS
}

\begin{abstract}
SUMMARY
The authors have made an attempt to construct a multi-channel data acquisition system for vibroacoustic signals, collected for analysis of acoustic field distributions in enclosed rooms and determination of surface acoustic impedance values at the wall surfaces. The scope of the study required a synchronic registration of acoustic pressure by 24 measurement microphones, determination of the phase-shift angles between the measured signals and determination of the vibration velocity for the loudspeaker diaphragm. The paper presents the first stage of the research, directly related to the multi-channel system for registration and analysis of vibroacoustic signals. The constructed research tools, due to their modular structure, can be adapted to new tasks, extended by adding new elements (further measurement cards, microphones, accelerometers etc.), what ensures great flexibility and suitability of the system for realization of advanced acoustical measurements. Open source code and users request for specialized acoustic analyses make the developed software packages a highly prospective research tool both for today and tomorrow.
\end{abstract}

Keywords: measurement systems, acoustic impedance, synchronous measurement, acoustic measurements

\section{WIELOKANAEOWY SYSTEM AKWIZYCJI SYGNAEÓW WIBROAKUSTYCZNYCH}

Autorzy podjęli zadanie budowy wielokanałowego systemu akwizycji sygnałów wibroakustycznych na potrzeby analizy rozkładów pola akustycznego w pomieszczeniach $i$ wyznaczania wartości impedancji akustycznej powierzchni ścian. Program badań wymagat synchronicznej rejestracji ciśnienia akustycznego przez 24 mikrofony pomiarowe, wyznaczenia kąta przesunięcia fazowego między mierzonymi sygnałami oraz wyznaczenia amplitudy prędkości drgań membrany glośnika. W pracy przedstawiony jest pierwszy etap badań bezpośrednio zwiazany z wielokanałowym systemem rejestracji i analizy sygnałów wibroakustycznych. Zbudowano narzędzia, które dzięki modułowej strukturze moga być dostosowywane do nowych zadań, rozszerzane o nowe elementy (kolejne karty pomiarowe, mikrofony, akcelerometry itp.), co stanowi o dużej przydatności powstatego systemu do zaawansowanych pomiarów akustycznych. Otwarty kod źródtowy oraz autorskie zapotrzebowanie na specjalistyczne analizy akustyczne tworza z opracowanych pakietów programowych w petni rozwojowe narzędzie badawcze na dziś i na przyszłość.

Slowa kluczowe: systemy pomiarowe, impedancja akustyczna, pomiar synchroniczny, pomiary akustyczne

\section{INTRODUCTION}

In many research and diagnostic problems in vibroacoustics one encounters tasks related to synchronic acquisition of big volumes of measurement data, acquired from parameter distributions of acoustic field surrounding the examined objects or located inside the objects. Such tasks are usually carried out in the first stage of vibroacoustic signal analysis, preparing the data for further processing or interpretation. The basis for construction of a system capable of executing such a task is the proper formulation of the research objectives and arrangement of a proper hardware measurement system. The data acquisition usually comprises a sequence of steps:

- Defining the measured quantities.

- Acquisition of signals from the sensors.

- Transmission to the recording device.

- Time sampling.

- Value quantization.

- Signal processing for the analysis requirements.
The authors have made an attempt to construct a multi-channel data acquisition system for vibroacoustic signals, collected for analysis of acoustic field distributions in enclosed rooms and determination of surface acoustic impedance values at the wall surfaces (Piechowicz et al. 2011). The proposed research methodology required completion of several stages consisting of preparatory tasks:

1. Construction of a model measurement test stand - selection of equipment, positioning of the measuring microphones, specification of the measured quantities.

2. Elaboration of a dedicated software package for acquisition of the measured data.

3. Elaboration of the software used for analysis and processing of the data collected from the measurements.

4. Construction of the 3D computer model for the examined room.

5. Development of specialized software for calculation of the surface impedance of bounding walls, using the inverse boundary element method. 
Because of new, nonstandard procedures introduced to the problem solution the scope of the research activity has been divided into two parts:

- Studies of the model room.

- Studies carried out in the real-world room.

In the first part of the study the required measurement quantities have been defined (the averaged amplitudes of acoustic pressure, phase-shift angles between the individual acoustic signals registered in the measurement, vibration velocity for the sound source diaphragm). Then the additional requirements have been formulated, regarding the configuration of the measurement setup, positioning of the measuring microphones and software used for measuring, recording and analysis of measured signals. Functioning of the whole system has been tested and verified by carrying measurements in a specially made model room.

The second part of the study comprised a construction of numerical models of the examined objects, elaboration of software for simulation of acoustic field distributions, analysis of the results and introducing corrections if necessary (Piechowicz 2011).

The paper presents the first stage of the research, directly related to the multi-channel system for registration and analysis of vibroacoustic signals.

\section{CONFIGURATION \\ OF THE MEASUREMENT CIRCUIT}

The scope of the study required a synchronic registration of acoustic pressure by 24 measurement microphones, determination of the phase-shift angles between the measured signals and determination of the vibration velocity for the loudspeaker diaphragm. The measurement setup also included a generator of sinusoidal and noise signals for stimulation of the enclosed space volume (model room or the real-world room under examination). For the measurements of the sound field parameters a dedicated multi-channel data acquisition system has been constructed, based on the PXI hardware platform. The system included NI PXI-1042Q type chassis, NI PXI-8196 controller (see Fig.1) and the following measurement cards:

- three measurement cards type NI PXI-4472B with the following basic features:

- eight simultaneously sampled vibration-optimized analog inputs,

- maximum sampling rate $102.4 \mathrm{kS} / \mathrm{s}$,

- measurement range $\pm 10 \mathrm{~V}, 24$ bit resolution;

- one NI PXI-4461 measurement card:

- two simultaneously sampled analog inputs:

- maximum sampling rate $204.8 \mathrm{kS} / \mathrm{s}$,

- two simultaneously updated analog outputs:

- maximum sampling rate $204.8 \mathrm{kS} / \mathrm{s}$,

- maximum measurement range $\pm 42.4 \mathrm{~V}$; 24 bit resolution.

Registration of the measured signals has been carried out by:

- 24 professional 1/4" matrix microphones,

- laser vibrometer.

The measurement setup included also:

- amplifier,

- loudspeaker,

- the elements positioning the measurement microphones.

The measurement circuit has been calibrated both in amplitude and phase-shift angle using an acoustic calibrator with a specialized 6-way attachment, allowing simultaneous calibration of six $1 / 4$ " microphones. The analog output of the NI PXI-4461 card has been used for generation of the tonal signal stimulating the boundary elements of model room or the real-world object, and the 25-th measurement channel (one of the two analog input channels of the NI PXI-4461 card) has been used for registration of the laser vibrometer signal, the device dedicated to the measurements of the vibrating surface (loudspeaker diaphragm) displacement, using the interference effects.
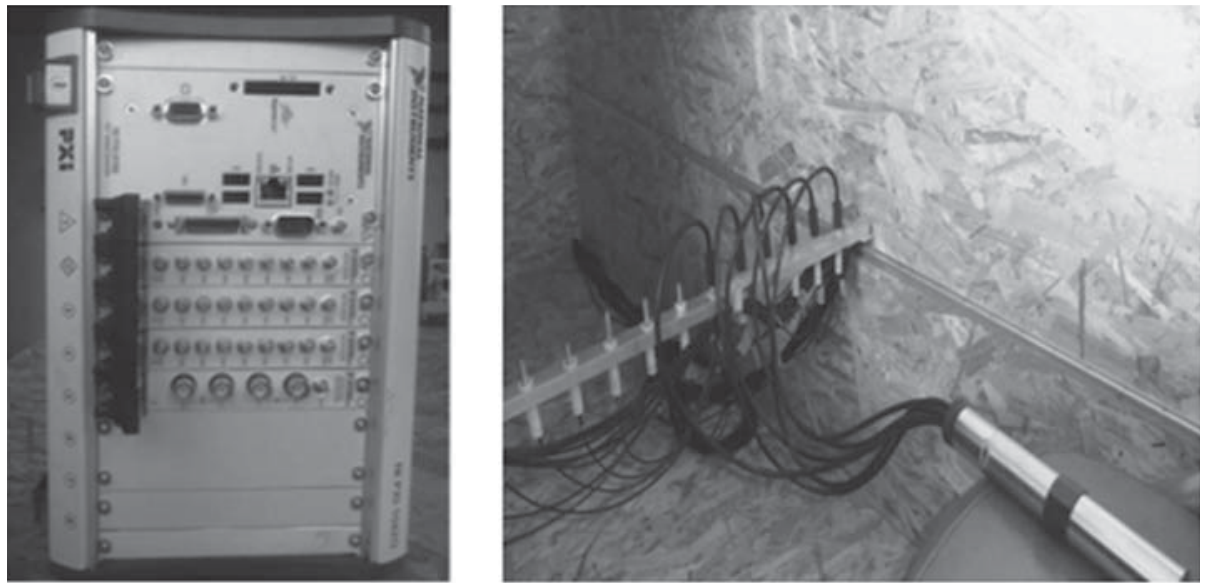

Fig. 1. The NI PXI 1042Q chassis with three NI PXI 4472B cards and one NI PXI-4461 card (a), The model room with a line of microphones (b) 
The PXI (PCI eXtension for Instrumentation) platform includes the PXI Trigger Bus, what allows full measurement synchronization between individual modules. PXI makes use of all advantages offered by the standard software and hardware PCI architecture, including fast data transfer. The fast PCI bus, used by the PXI, when combined with integrated clock rate signal and triggering, allows a convenient implementation of PXI devices to synchronic, multi-channel measurements. In short the PXI is a modular platform for measuring devices, which allows realization of various measurement functions controlled by the supervising PC.

\section{THE MEASUREMENT SOFTWARE}

For realization of the acoustic measurements and processing of the measured data two dedicated software packages have been developed by the authors:

- Multichannel Data Acquisition System,

- Spectral Analyzer.

Both software packages have been written in the LabView 2010 environment. The LabVIEW environment includes advanced numerical libraries and the necessary drivers enabling the cooperation with various external devices. The DAQmx drivers enable access to all the modules of the PXI platform, what allows the hardware configuration according to the user's own needs. The applications allowed the creation of virtual measurement devices for specialized measurements, using multi-channel signal registration, and for the later signal analysis. During the measurement process the acoustic signals are registered on the hard disk in the lossless TDMS standard. The lossless registration of the time dependencies allows convenient re-analysis of the data after each software modification.

The constructed tools, due to their modular structure, can be adapted to new tasks, extended by introducing new elements (additional measurement cards, microphones, accelerometers etc), what ensures the systems suitability for performing new, more advances acoustic measurements.

\subsection{Multichannel Data Acquisition System}

The multithreading architecture of the Multi-Channel Data Acquisition System (see Fig. 2) is dedicated to synchronic acquisition of signals from multiple channels (26 measurement channels), which is synchronized with the measurements of generation parameters of tonal or noise signals ( 2 channels). This type of architecture, has also been used in (Batko et al. 2012).

In the acquisition thread the measurement process has been configured in such a way that individual signals, measured and generated by various measurement cards, are fully synchronized. The signal acquisition has been synchronized with the voltage signal generating the acoustic stimulation using the loudspeaker, so that the phase-shift angles between the individual registered signals can be easily analyzed.

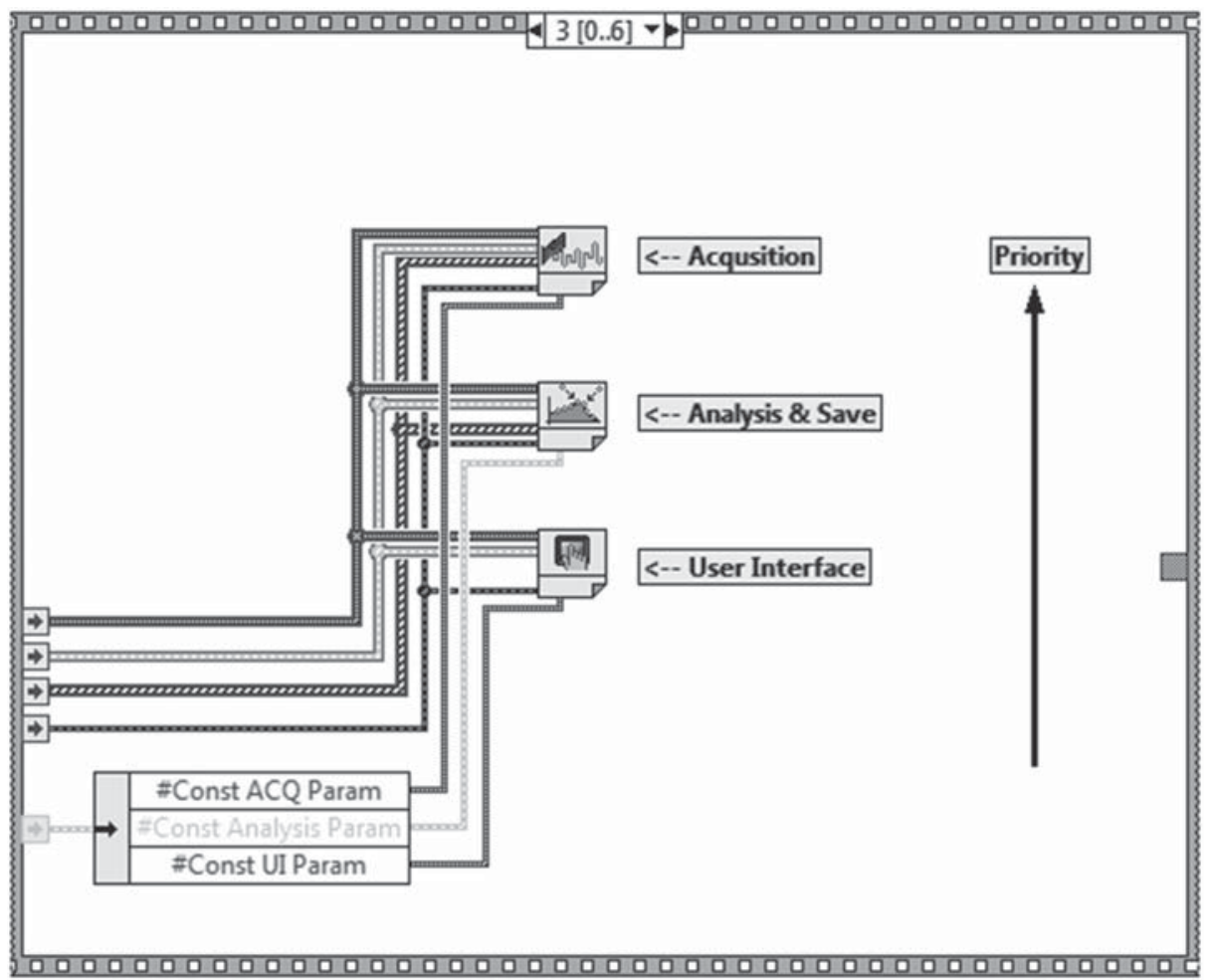

Fig. 2. Structure of the Multi-channel Data Acquisition System application, developed in the LabVIEW environment 


\section{Star Trigger Bus}

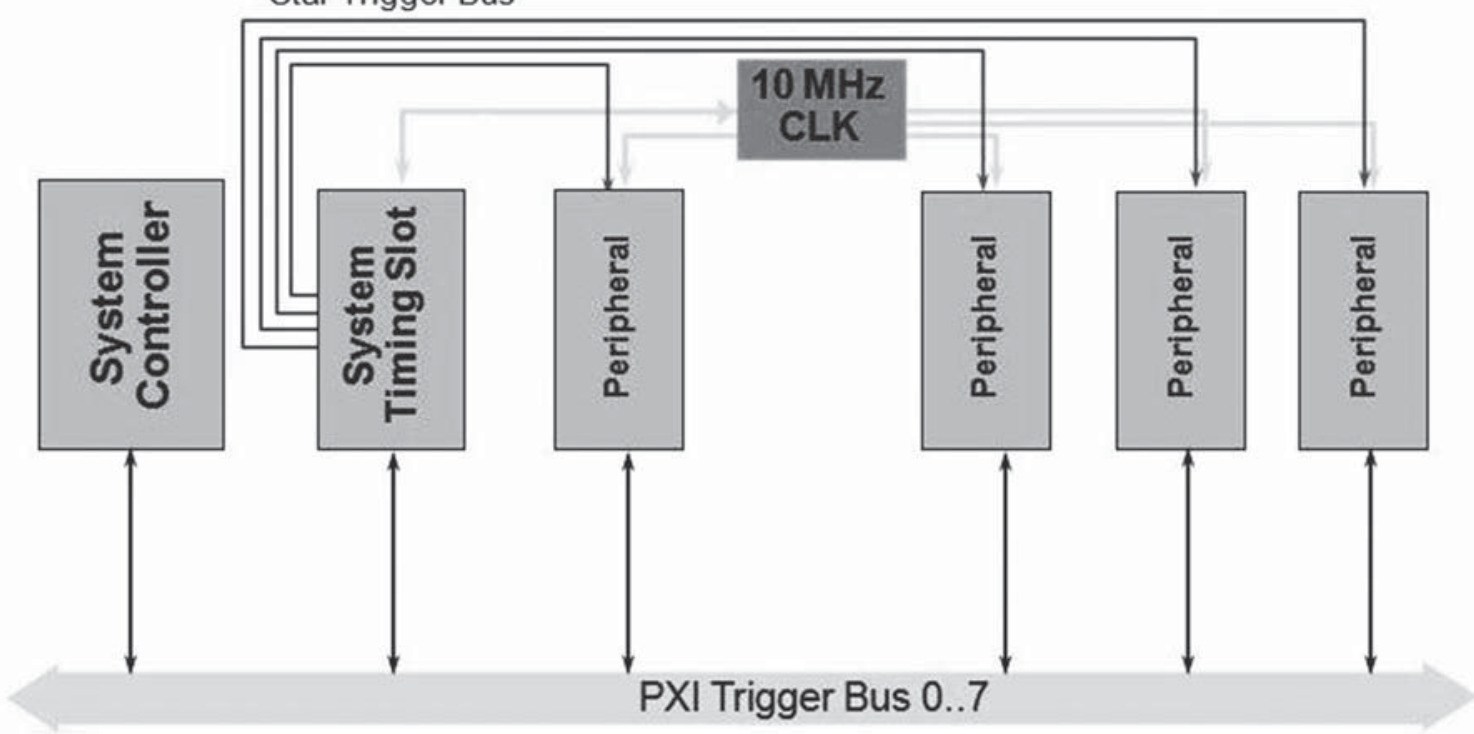

Fig. 3. Block scheme of synchronization lines connection in the PXI platform (National Instruments 2007)

Measurement triggering is executed using the PXI Trigger Bus (Fig. 3), which enables simultaneous measurement triggering for all the measuring cards. The maximal delay on the PXI Trigger Bus is estimated to be about 80 ns. In addition all the measurement cards execute the sampling of analog signals using the Sample Clock, located in the NI PXI-4472B card, installed in the System Timing Slot.

The acquisition thread works with the highest priority, in order to ensure the lossless acquisition of the measured data. The collected data are sent to data analysis thread, using the FIFO queue.

The next thread executes the preliminary data processing for the purpose of later data presentation on the user's interface panel. That module also includes the calibration of the measurement system and the recording of measurement data.

The duration of the calibration are 5 seconds, during which time the average value is calculated for each microphone sensitivity $\operatorname{sen}_{\text {mean }}$ (1) and the phase shift relative to the first microphone $\varphi_{\text {mean }}(2)$, at a given signal from the calibrator standard six-pin special adapter (Fig.1).

$$
\begin{aligned}
& \text { sen }_{\text {mean }}=\frac{1}{n} \sum_{i=1}^{n} \operatorname{sen}_{i} \\
& \varphi_{\text {mean }}=\frac{1}{n} \sum_{i=1}^{n} \varphi_{i}
\end{aligned}
$$

where:

$n$ - number of measurement windows;

$\operatorname{sen}_{i}-$ microphone sensitivity determined in a single measurement window $[\mathrm{mV} / \mathrm{Pa}]$;

$\varphi_{i}$ - phase shift relative to the first microphone set in a single measurement window [rad].
In the whole structure the supervision and control of individual threads is executed by the User Interface thread, which sends the proper commands to the other threads and deals with the messages concerning possible errors. It is also responsible for the communication between the user and the program (modification of the registration parameters, presentation of the results).

During the measurement the monitor screen presents the time dependencies and power spectra registered from individual measurement channels and simultaneous preview of acoustic pressure RMS values for all the measurement channels. Figure 4 presents the main window of the Multi-channel Data Acquisition System application.

The application also realizes the generation of sinusoidal signal of a specified frequency and amplitude. Additionally a Gaussian noise signal of required amplitude can be also generated.

\subsection{Spectral Analyzer}

The collected and written to TDMS type disc file measurement data are analyzed using the analysis application called Spectral Analyzer. The application is compatible with the Multi-channel Data Acquisition System described above. In the application band analysis functions for a selected signal have been implemented for frequency bands of 1/24, 1/12 and $1 / 3$ octave width as well as full octave analysis. The frequency band analysis is carried out with specified additional parameters like: bandwidth, correction curve type (A, B, $\mathrm{C}$ and linear), averaging method and the range of the analyzed frequency band. Additionally the user can carry out the spectral analysis in a single frequency band of a selected range and calculate the amplitude-frequency and phase angle-frequency characteristics of tested objects. 


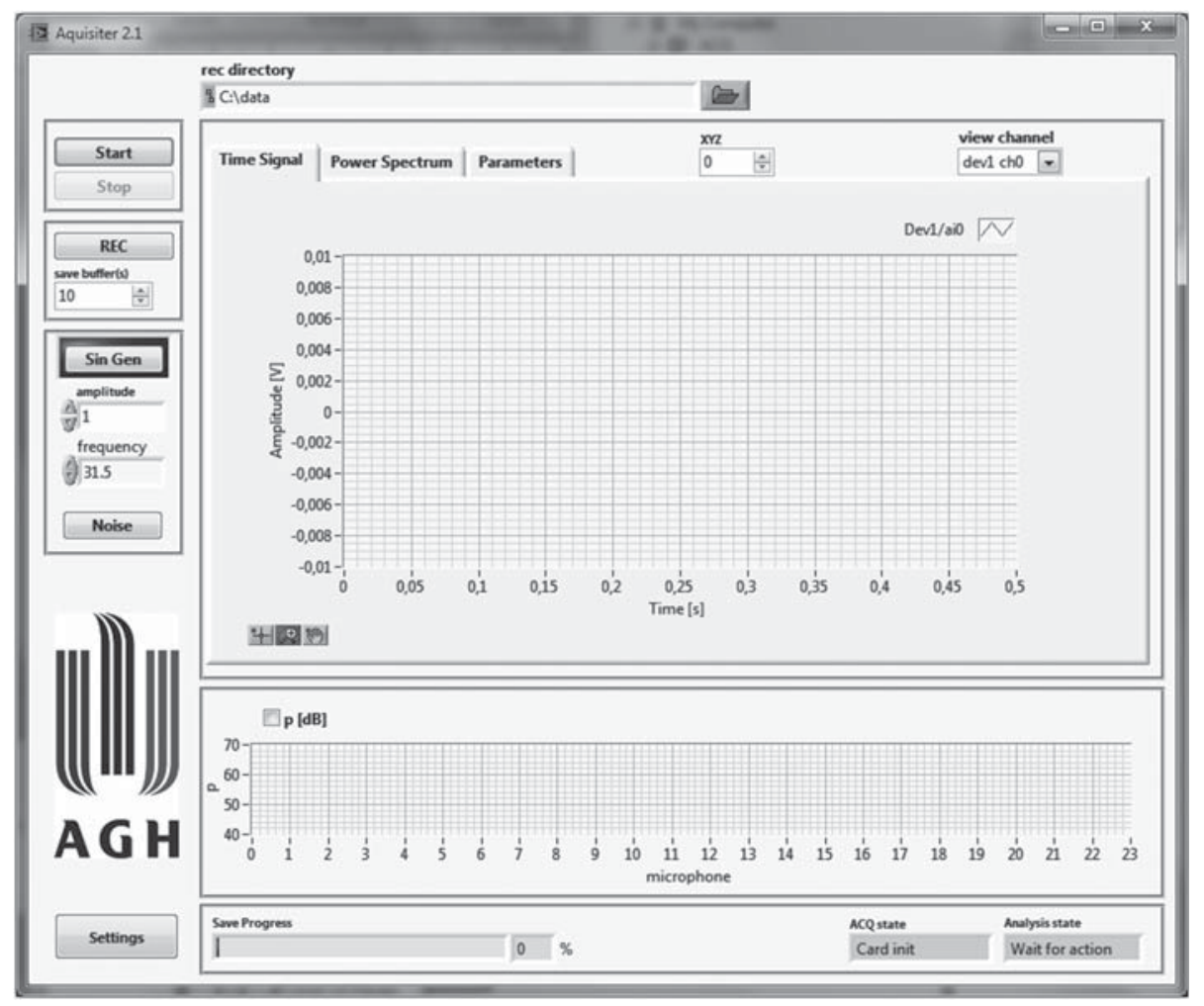

Fig. 4. The main window of the Multi-channel Data Acquisition System

The Spectral Analyzer application, dedicated to analysis of written time signals, includes also the function of automated analysis of all the data written in TDMS type files (see Fig. 5 and Fig. 6). The application automatically executes the amplitude-frequency analysis and phase angle analysis for the signals measured with Gaussian noise stimulation for the selected measurement channel. If the signal has been measured with sinusoidal stimulation it calculated the phase-shift angle between the diaphragm velocity measurement signal (for the loudspeaker emitting the stim-

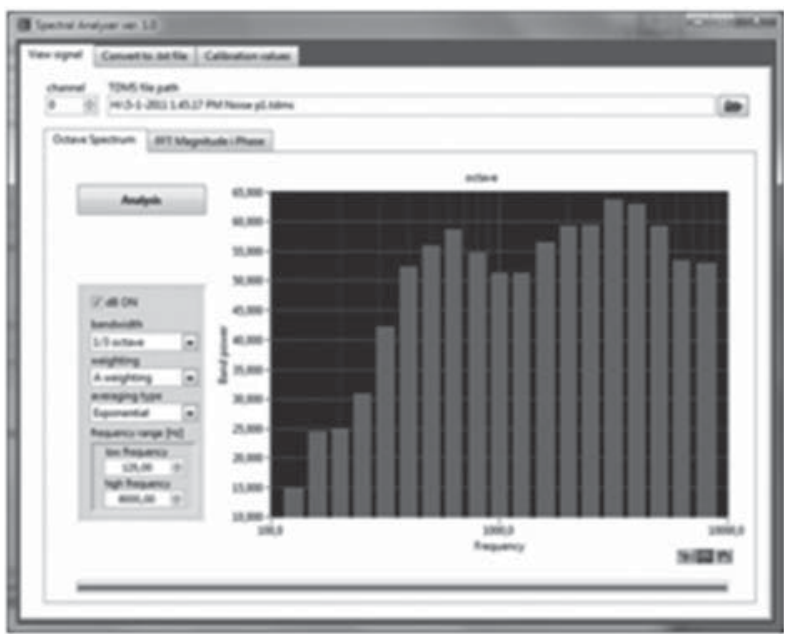

Fig. 5. The Spectral Analyzer application, Octave Spectrum Tab ulation signal) and the signals registered by the individual measurement microphones. It also calculates the RMS values for signals registered by individual microphones and for the channel registering the loudspeaker diaphragm vibration velocity.

The results of the analyses are written to two TXT files. One of the files contains the results of analysis for signals measured with sinusoidal stimulation, while the results of analyses for signals measured with the noise type stimulation are written to the other (separate) file.

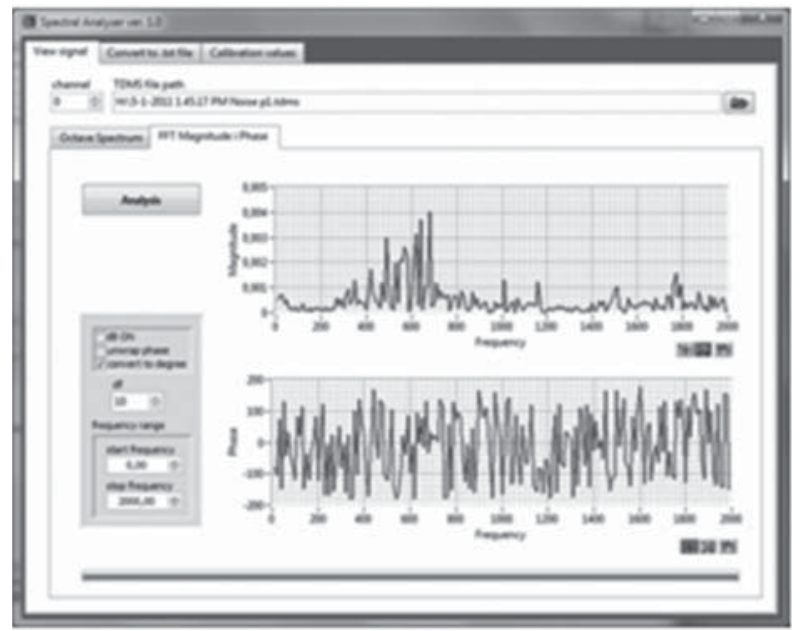

Fig. 6. The Spectral Analyzer application, FFT Magnitude and Phase Tab 


\section{SUMMARY}

Multi-channel system for acquisition of vibroacoustic signals has been constructed for realization of a specific research program. Its structure and accompanying software allow its further development by multiplying the number of measurement channels, realized by the possibility to add further measurement cards and to connect further sensors. The dedicated software, written in the LabVIEW environment, allows creation of virtual measurement devices for specialized, multi-channel data acquisition of vibroacoustic signals and spectral analysis. The measured data are written as time-dependent sound pressure values, what allows repeated analyses after each modification of the analyzing procedure. The TDMS data recording standard in addition to time-dependent functions allows also appending description notes for the recorded signals as well as measurement parameters.

The constructed research tools, due to their modular structure, can be adapted to new tasks, extended by adding new elements (further measurement cards, microphones, accelerometers etc.), what ensures great flexibility and suitability of the system for realization of advanced acoustical measurements. Open source code and users request for specialized acoustic analyses make the developed software packages a highly prospective research tool both for today and tomorrow.

This paper was carried out in the part of the activities statutory Department of Mechanics and Vibroacoustics AGH UST in Cracow.

\section{References}

National Instruments 2007, Synchronization Explained, http://www.ni.com/. Batko W., Korbiel T. Pawlik P. 2012, Analiza eksperymentalna przydatności trajektorii fazowych do diagnostyki maszyn wirujących, Problemy Eksploatacji - Maintenance Problems, No. 1, pp. 7-15.

Piechowicz J. et al. 2011: Sprawozdanie z realizacji projektu badawczego N N504 342536 Zastosowanie metody inwersji $w$ analizie własności akustycznych pomieszczeń przemysłowych, AGH Kraków, (maszynopis)

Piechowicz J. 2011, Estimating surface acoustic impedance with the inverse method, International Journal of Occupational Safety and Ergonomics, 17, 3, pp. 271-276. 